\title{
Response of reservoir atrazine concentrations following regulatory and management changes
}

\author{
K.W. King, N.R. Fausey, R. Dunn, P.C. Smiley, Jr., and B.L. Sohngen
}

\begin{abstract}
Since the early 1990s, atrazine concentration exceeding the drinking water standard of $3 \mu \mathrm{g} \mathrm{L}^{-1}$ (parts per billion) in US drinking water supplies has been identified as a costly and major water quality concern. Atrazine levels in Columbus, Ohio, tap water reached $8.74 \mu \mathrm{g} \mathrm{L}^{-1}$ in the early 1990 s, leading to a watershed-based approach aimed to reduce elevated atrazine concentrations. In 1999, a special Environmental Quality Incentives Program (EQIP) was implemented in the watershed that feeds Hoover Reservoir, the primary drinking water supply for Columbus, Ohio. Through EQIP, the Natural Resource Conservation Service (NRCS) offered financial incentives to farmers and operators to apply alternative pesticide management practices in an effort to reduce atrazine concentrations in the reservoir and maintain the concentrations below the drinking water standard. Monthly reservoir atrazine concentrations measured from 1985 through 2005 represent three distinct time periods with respect to atrazine management: no label restrictions (1985 to 1992), post label restrictions (1993 to 1998), and post label restrictions plus EQIP implementation (1999 to $2005)$. Significant $(p<0.05)$ reductions in mean monthly reservoir atrazine concentrations were noted between all three time periods: no label restrictions $\left(2.27 \mu \mathrm{g} \mathrm{L}^{-1}\right)>$ post label restrictions $\left(1.99 \mu \mathrm{g} \mathrm{L}^{-1}\right)>$ post label restrictions plus EQIP implementation $\left(1.18 \mu \mathrm{g} \mathrm{L}^{-1}\right)$. Regression analyses indicated that May through June precipitation and hectares enrolled in the EQIP pest management practice (Natural Resource Conservation Service Practice 595) were the two most important predictors of reservoir atrazine concentration. Additionally, for every dollar spent on the NRCS 595 pest management practice cost shared through the EQIP program, a US $\$ 2.73$ benefit for the City of Columbus was realized through reduced drinking water treatment costs to remove atrazine. For farmers and operators, atrazine is an economically viable and effective herbicide for corn production. This study indicates that annually eliminating atrazine application on approximately $16 \%$ of the crop production acres may reduce and maintain reservoir atrazine concentrations below drinking water thresholds.
\end{abstract}

Key words: agriculture — conservation—pesticides—watershed—water quality

\begin{abstract}
Historically, streams and rivers were important to the establishment of communities and centers of commerce. A watercourse was vital for transportation, water supply, and disposal of wastes. Early local efforts to control water pollution were based on principles of nuisance and the balance of competing uses. Population growth and industrial development brought water pollution concerns to national attention after World War II. Rachael Carson's 1962 book, Silent Spring, brought to the forefront ecological impacts of chemicals being widely applied to enhance agricultural production.
\end{abstract}

A shift in people's thinking began to emerge toward a new ethical premise that water should be clean and free of agricultural, industrial, and urban contaminants.

Approximately two-thirds of the water withdrawn for public water supply in the United States originates from surface sources (Kenny et al. 2009). Over 11,000 community water supply systems in the United States store, treat, and distribute an average $749 \mathrm{~L}$ (198 gal) of water per capita per day. The majority of these surface water supplies are fed by drainage waters originating in agricultural dominated watersheds. Discharge waters from agricultural lands carry sediments, nutrients, pesticides (including fungicides, herbicides, and insecticides), and/or other contaminants, such as pathogens and pharmaceuticals (Ritter et al. 2002; Smiley et al. 2010). Of these pollutants, atrazine continues to receive more attention and research than any other pesticide due to its widespread use and potential impacts on aquatic life (Rohr and McCoy 2010). Conventional treatment plant filtering processes are limited in their ability to remove atrazine and an array of other dissolved pollutants (Westerhoff et al. 2005; Stackelberg et al. 2004). These waters are then delivered to the public.

Atrazine (6-chloro-N2-ethyl-N4-isopropyl-1,3,5-triazine-2,4-diamine) is a systemic triazine herbicide primarily used to control broadleaf weeds and some grasses in corn fields. Atrazine is registered for multiple uses, but its primary application is in crop production agriculture. Approximately 25 million $\mathrm{kg}$ (55 million $\mathrm{lb}$ ) of atrazine are applied annually in the United States Corn Belt (Vecchia et al. 2009), accounting for $72 \%$ of all atrazine applied nationally (USEPA 2006). In the US Corn Belt, atrazine is primarily applied in April and/or May as a preemergence herbicide.

Atrazine was first registered in 1958, followed by several changes and modifications resulting from federal regulations and the herbicide's detection and persistence in the environment. With respect to surface waters, the most significant label changes were added in 1992. In that revision, total annual application rates for corn were limited to $2.81 \mathrm{~kg}$ active ingredient (AI) ha ${ }^{-1}\left(2.5 \mathrm{lb} \mathrm{AI} \mathrm{ac}^{-1}\right)$ in a split application of $1.68 \mathrm{~kg} \mathrm{AI} \mathrm{ha}^{-1}(1.5 \mathrm{lb} \mathrm{AI}$ $\mathrm{ac}^{-1}$ ) preemergence and $1.12 \mathrm{~kg} \mathrm{AI} \mathrm{ha}^{-1}$ (1 lbs $\left.\mathrm{AI} \mathrm{ac}^{-1}\right)$ postemergence. This was a significant reduction from the previously allowable 3.37 $\mathrm{kg} \mathrm{AI} \mathrm{ha} \mathrm{H}^{-1}\left(3 \mathrm{lbs} \mathrm{AI} \mathrm{ac}^{-1}\right)$ preemergence application rate. Additionally, atrazine's use for broadleaf weed control in noncropland was eliminated. In 1991, the US Environmental Protection Agency (USEPA) Office of Water established a $3 \mu \mathrm{g} \mathrm{L}^{-1}$ maximum contaminant

Kevin W. King is a research agricultural engineer, Norm R. Fausey is a research soil scientist, and Peter C. Smiley, Jr., is a research ecologist for the USDA Agricultural Research Service in Columbus, Ohio. Roderick Dunn is a chemist working for the City of Columbus, Columbus, Ohio, and Brent L. Sohngen is an economist at The Ohio State University, Columbus, Ohio. 
level for atrazine in drinking water. Despite these efforts, atrazine in surface waters continues to be of concern, and atrazine contaminated water requires additional treatment prior to human consumption.

Alarming concentrations of agricultural contaminants, particularly atrazine, have occurred within tap water in metropolitan areas in the midwestern United States (Brian 1995). Specifically, atrazine was detected in tap water samples in 28 of 29 cities with the greatest concentration $\left(18 \mu \mathrm{g} \mathrm{L}^{-1}\right)$ occurring in Danville, Illinois (Brian 1995). Columbus, Ohio, ranked third with an average concentration of $3.54 \mu \mathrm{g} \mathrm{L}^{-1}$ and a maximum concentration of $8.74 \mu \mathrm{g} \mathrm{L}^{-1}$ (Brian 1995). In the Brian (1995) study, $100 \%$ of the tap water samples collected in Columbus, Ohio, tested positive for atrazine. In many cases, tap water concentrations continuously exceeded the USEPA maximum contaminant level for atrazine. More recently, Coupe and Blomquist (2004) provided an assessment of both source and finished waters of 12 community water systems in the United States. Atrazine was detected in every source and finished drinking water system sampled, although the concentrations in the finished waters were generally much less than in the raw water (Coupe and Blomquist 2004), a result of treatment with powdered activated carbon (PAC). Additionally, atrazine is an herbicide of concern statewide in Ohio, and 14 watersheds have been placed on the Ohio Environmental Protection Agency (EPA) watch list due to the occurrence of elevated atrazine concentrations (Ohio EPA 2008, 2010).

Monitoring results such as these has prompted the registrants and research community to explore different options that permit the safe use of atrazine while protecting drinking water supplies and securing crop production. One approach to protect drinking water supplies from elevated atrazine concentrations is to address the problem prior to delivery to customers (i.e., scrub the water with activated carbon) (Ribaudo and Bouzhar 1994). This approach is proven yet very expensive. An alternative approach is to address the source of the supply by reducing the concentrations and/or application within the upstream watershed (Ribaudo and Bouzhar 1994). Enhancing drinking water supplies should originate at the source of the supply rather than at the treatment facility because of the potential for treatment facility failure (Davies and Mazumder
2003). Healthy watersheds (i.e., those with reduced concentrations of agricultural contaminants) lead to enhanced water quality for agricultural, industrial, and domestic uses and improved aquatic habitat conditions (Postel and Thompson 2005). Many nonpoint source pollutant reduction watershed projects in the United States have not performed to expectations (Meals et al. 2010). However, some successes have been documented, such as Bryant et al. (2008) who measured substantial reductions in phosphorus loadings from the Cannonsville Watershed, a New York City water supply watershed. Adoption and implementation of conservation practices (i.e., stream bank fencing, cover crops, and precision animal feeding) reduced dissolved phosphorus loading by $50 \%$ and total phosphorus loading by $17 \%$.

Best management practices (BMPs) documented to be effective at curbing the downstream transport of atrazine include vegetated filter strips (Mickelson et al. 2003), wetlands (Moore et al. 2000), application timing (Rector et al. 2003), incorporation (Gorneau et al. 2001), and reduced rate or split application (Devlin et al. 2000). Tillage effects on atrazine loss are inconclusive (Devlin et al. 2000). On some soils, no-till will reduce atrazine losses while on others it may increase losses. Reichenberger et al. (2007) reviewed multiple publications on mitigation strategies specific to pesticides and concluded that buffers, primarily edge-of-field buffers, and wetlands were demonstrated to be most effective at reducing pesticide transport.

The source water approach relies on farmer adoption and implementation of BMPs to reduce offsite transport. Persuading landowners and operators to voluntarily adopt and implement pesticide BMPs involving pesticide management is often a hard sell because the practices generally increase crop production costs (Valentin et al. 2004). Additionally, some BMPs are costly for producers because they take land out of production (e.g., wetlands). However, selected BMPs are cost sharable through current Natural Resources Conservation Service (NRCS) programs. These cost shares are often a necessary incentive to entice and secure farmer participation. However, even with these incentives, the extent and duration to which operators are willing to participate in a program or adopt a practice is variable (Smithers and Furman 2003).
Several real world examples exist that demonstrate the value of cooperative, community-based efforts to work with local landowners to voluntarily adopt practices that conserve and enhance natural resources (Hargrove and Devlin 2010). But there is both inadequate record and scientific review of the effects of such voluntary, incentivebased efforts on atrazine losses and the quality of water for use in drinking water systems. The objective of this research was to compare atrazine concentrations in Hoover Reservoir (a City of Columbus, Ohio, drinking water supply reservoir) during three time periods representing different atrazine management strategies in the watershed.

\section{Materials and Methods}

Watershed Description. The Upper Big Walnut Creek Watershed (UBWC) is a 492 $\mathrm{km}^{2}$ (190 $\left.\mathrm{mi}^{2}\right)$ United States Geological Survey 10-digit (HUC 05060001-13) watershed located in central Ohio (figure 1). The watershed is identified as an Agricultural Research Service benchmark watershed being evaluated as part of the Conservation Effects Assessment Project (Mausbach and Dedrick 2004; King et al. 2008). The UBWC was identified as a priority impaired watershed by the Ohio EPA in their 1998, 2000, and 2003 303(d) lists (Ohio EPA 2005) because it was not meeting established water quality standards. Atrazine, in particular, is a contaminant of concern in the UBWC because concentrations within the Hoover Reservoir have periodically exceeded the drinking water standard (Malcolm Pirnie Inc. 1999).

The UBWC is characterized by 686 $\mathrm{km}(426 \mathrm{mi})$ of perennial and intermittent streams that drain to Hoover Reservoir. Hoover Reservoir is the primary water supply for approximately 800,000 residents in Columbus and surrounding communities. The reservoir was completed in 1955 and has a surface area of approximately 1,200 ha $(2,960 \mathrm{ac})$ at normal pool elevations and 1,860 ha $(4,600 \mathrm{ac})$ at maximum capacity. The reservoir is $13.7 \mathrm{~km}$ (8.5 mi) in length with a residence time of 180 days.

Cropland production agriculture comprises the largest land use classification within the watershed (approximately 55\% per the Delaware, Ohio, county auditor's 1999 land use and land cover survey). The primary agricultural crops are corn, soybeans, and wheat. Management primarily includes 


\section{Figure 1}

Location of Upper of Big Walnut Creek Watershed and Hoover Reservoir within Ohio and the United States.

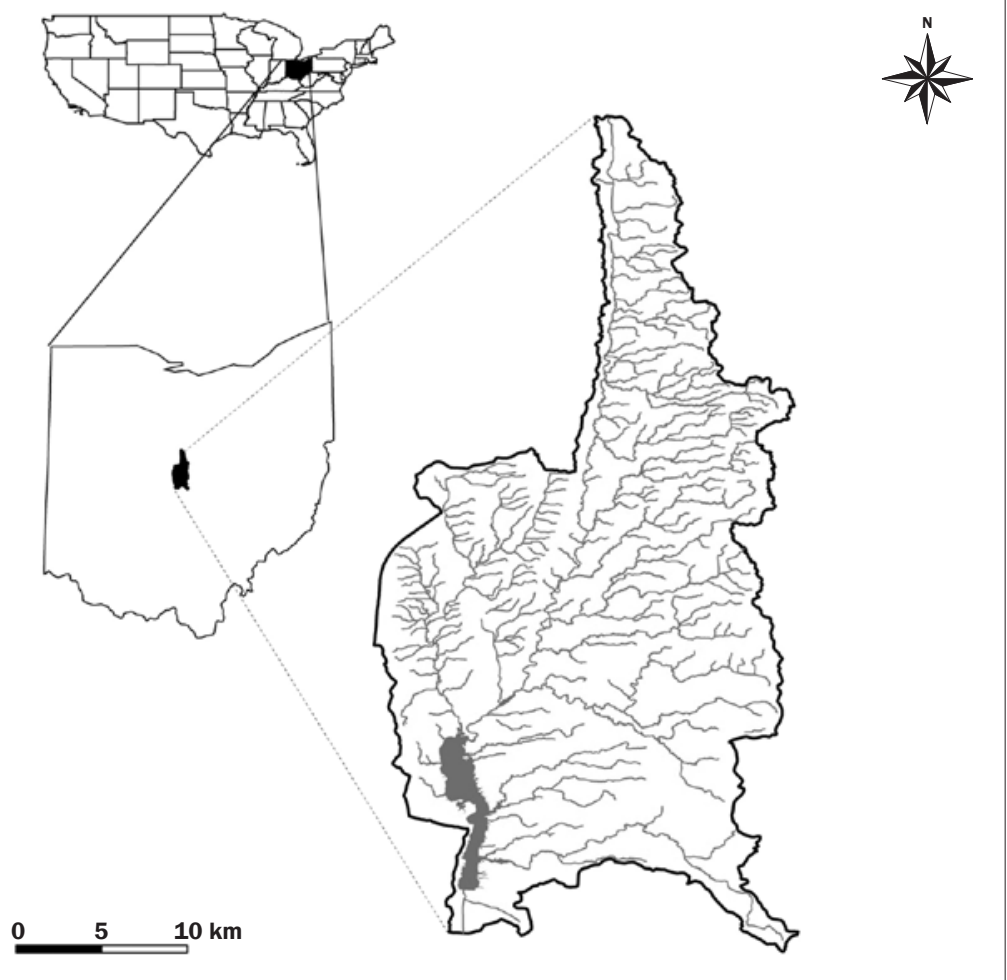

conservation tillage, fertilization, and pesticide applications. An extensive portion of the watershed used for agricultural production is systematically tile drained, especially in the southern half of the watershed. Soils in the watershed are mostly moderately fine-textured, moderately well drained to very poorly drained, and consist primarily of Cardington (9.6\%), Centerburg (20.4\%), Bennington (34.6\%) silt loams, and Pewamo (17.2\%) silty clay loam. Approximately $18 \%$ of the watershed is comprised of other minor soils and water.

The UBWC is located in the humid continental-hot summer climatic region of the United States. The climate provides for approximately 160 growing days per year, generally lasting from late April to midOctober. Average daily temperatures range from a minimum of $-9.6^{\circ} \mathrm{C}\left(14.7^{\circ} \mathrm{F}\right)$ in January to a maximum of $33.9^{\circ} \mathrm{C}\left(93^{\circ} \mathrm{F}\right)$ in July. Thunderstorms during the spring and summer produce short-duration, intense rainfalls. Moisture in the form of frozen precipitation or snow averages $500 \mathrm{~mm}$ (19.7 in) annually and occurs primarily from December to March. The 30-year average rainfall near the southwest portion of the watershed is $985 \mathrm{~mm}$ (38.8 in). Monthly distribution of rainfall exhibits a bimodal distribution with a primary peak in late spring and early summer and a secondary peak in late fall and early winter.

Water Quality Partnership. In response to the popular press articles and reports regarding elevated concentrations of atrazine in drinking water, a farmer-led water quality partnership was initiated in 1996 with the goal of identifying and promoting conservation practices aimed at reducing atrazine concentrations in Hoover Reservoir. In September 1997, the Upper Big Walnut Creek Water Quality Partnership was formally organized and obtained US $\$ 100,000$ from the state legislature of Ohio.The purpose of the state funding was to help the agricultural community voluntarily demonstrate their commitment and organize resources to implement conservation management practices that improve water quality in the watershed. Working with the Upper Big Walnut Water Quality Partnership, an all-volunteer group of local farmers, the Delaware, Morrow, Knox, and Licking County Soil and Water Conservation Districts and the USDA's Natural Resources Conservation Service and Farm Services Agency sought out producers who were using atrazine within the watershed to voluntarily adopt an alternative atrazine management strategy aimed at reducing atrazine concentrations in Hoover Reservoir.

Special Environmental Quality Incentives Program. The Environmental Quality Incentives Program (EQIP) was established in 1996 (P.L. 104-127) as an amendment to the Food Security Act of 1985 (Farm Bill). It was reauthorized in the Farm Security and Rural Investment Act of 2002 and again in the Food, Conservation, and Energy Act of 2008. The program promotes environmental awareness and stewardship by providing financial, technical, and educational assistance to landowners and operators. In general, farmers voluntarily enter into a contract (usually three to five years) with the NRCS to adopt and implement one or more conservation practices.

In 1997, the partnership promoted the need for and received authorization and funding for a special EQIP in the UBWC to address atrazine concerns in Hoover Reservoir. The primary focus of the special EQIP was on reducing atrazine usage within the watershed through the promotion of alternative pesticide management practices using pest management (NRCS practice code 595). The initial sign-up period for the special EQIP was in 1998, with implementation commencing in 1999. This special EQIP was offered for additional sign-up periods annually through 2003.

Producers who enrolled in the special EQIP were provided four atrazine management options to choose from: (1) use an alternative herbicide other than atrazine; (2) use a reduced rate of atrazine; (3) incorporate atrazine; or (4) introduce a small grain, such as wheat, into the rotation. The management options offered were only on those crop areas that were planted to corn. Application of an alternative herbicide (i.e., any herbicide other than atrazine) or introducing a small grain into the rotation was cost-shared at US $\$ 37.06 \mathrm{ha}^{-1}$ (US\$15.00 $\left.\mathrm{ac}^{-1}\right)$. Selecting the US\$24.71 ha $\mathrm{ha}^{-1}$ (US\$10 ac ${ }^{-1}$ ) option required reducing atrazine application to a maximum of $1.12 \mathrm{~kg} \mathrm{ha}^{-1}\left(1 \mathrm{lb} \mathrm{ac}^{-1}\right)$ with a postemergent application program or incorporation below $12.7 \mathrm{~mm}$ (0.5 in) at label rates. If this option was selected, average annual soil erosion rates must equal or be below tolerance levels for dominant soils in the field. Finally, US $\$ 12.36 \mathrm{ha}^{-1}$ (US\$5 ac $\mathrm{ac}^{-1}$ ) was offered if atrazine application was reduced to $1.12 \mathrm{~kg}$ 
$\mathrm{ha}^{-1}\left(1 \mathrm{lb} \mathrm{ac}^{-1}\right)$ or less with no restriction on application timing.

The most popular option was the US\$37.06 $\mathrm{ha}^{-1}$ (US\$15 $\mathrm{ac}^{-1}$ ) payment for using an alternative herbicide other than atrazine. Once a field was enrolled, the funding was available for up to three times on a given field during the five year contract period. During the special EQIP period, the EQIP program dispersed approximately US $\$ 814,000$ for conservation practices in the UBWC. Approximately US $\$ 609,000$ of the total EQIP amount was for NRCS practice 595 (pest management) to address excess atrazine concentrations in Hoover Reservoir (table 1). The maximum amount of area receiving contract payment in any given year was 5,729 ha $(14,151 \mathrm{ac})$ in 2003 . Of that total area, 4,428 ha $(10,936 \mathrm{ac})$ or approximately $16 \%$ of the cropland in the watershed was receiving payment for atrazine management (table 1).

Sampling and Analysis. Hoover Reservoir water was sampled the first week of every month from 1985 to present. Water samples were collected by personnel from the City of Columbus, Ohio, from a floating boat dock located in the downstream third of the reservoir, close to the reservoir dam. Water samples were collected from the surface in $1 \mathrm{~L}(0.26$ gal) glass bottles, iced and returned to the City of Columbus laboratory. The samples were prepared following methods outlined in USEPA Method 507 (USEPA 1995). The $1 \mathrm{~L}$ samples were extracted with methylene chloride by shaking in a separatory funnel. Then the methylene chloride extract was isolated, dried, and concentrated during a solvent exchange to methyl tert-butyl ether to a final volume of $5 \mathrm{ml}\left(0.31 \mathrm{in}^{3}\right)$. The atrazine concentration in the extract was then measured using a gas chromatograph (Varian 3800, Agilent Technologies, Santa Clara, California) with a nitrogen-phosphorus detector. The laboratory is certified to analyze nitrogen, phosphorus, and pesticides by the Ohio EPA.

Statistical Analyses. Statistical analyses were conducted to determine if monthly reservoir atrazine concentrations differed among the three different time periods that represent different management strategies. Specifically, the time periods used were: (1) unrestricted application period from 1985 to 1992, (2) the period following label restrictions from 1993 to 1998, and (3) the post label restriction plus EQIP implementation

\section{Table 1}

Land area and Environmental Quality Incentives Program (EQIP) cost share payments for Natural Resources Conservation Service (NRCS) practice 595 (pesticide management) and all other EQIP practices (NRCS practice 328, conservation crop rotation; NRCS practice 329, no-till; NRCS practice 344, residue management; and NRCS practice 590, nutrient management) within Ohio's Upper Big Walnut Creek watershed for period 1999 to 2005.

\begin{tabular}{lcccc}
\hline Year & $\begin{array}{l}\text { Land receiving } \\
\mathbf{5 9 5} \text { payments } \\
\text { (ha) }\end{array}$ & $\begin{array}{l}\mathbf{5 9 5} \\
\text { payments } \\
\text { (US\$) }\end{array}$ & $\begin{array}{l}\text { Total land } \\
\text { receiving EQIP } \\
\text { payments (ha) }\end{array}$ & $\begin{array}{c}\text { Total EQIP } \\
\text { payments } \\
\text { (US\$) }\end{array}$ \\
\hline 1985 to 1998 & 0 & 0 & 0 & 0 \\
1999 & 541.3 & 20,211 & 722.3 & 27,110 \\
2000 & $1,620.9$ & 53,700 & $2,684.2$ & 81,870 \\
2001 & $2,906.0$ & 99,939 & $3,950.3$ & 142,504 \\
2002 & $2,623.3$ & 92,245 & $4,348.2$ & 143,724 \\
2003 & $4,427.6$ & 153,238 & $5,729.4$ & 201,420 \\
2004 & $4,105.5$ & 121,203 & $4,710.2$ & 152,776 \\
2005 & $1,962.6$ & 68,256 & $2,690.8$ & 94,792 \\
\hline 5 -year total & & 608,792 & & 814,196
\end{tabular}

period from 1999 to 2005. For each time period, each month represented one sample in the statistical analyses. Thus, period 1 (1985 to 1992) contained 96 samples, period 2 (1993 to 1998) contained 72 samples, and period 3 (1999 to 2005) contained 84 samples. Distributions of monthly atrazine concentrations for each time period did not meet the assumptions of normality and equal variance. Therefore, the two factor analysis of variance (ANOVA) coupled with the Tukey pairwise multiple comparison test was conducted on rank transformed values. Rank transformation is commonly recommended in these situations, and its use with a parametric test is the equivalent of a nonparametric two factor ANOVA (Conover 1999).

Additionally, statistical tests were conducted to evaluate if climatic and cropping characteristics were different across the three time periods. Annual and total April through June precipitation amounts as well as the amount of corn hectares were evaluated using the Kruskal-Wallis test paired with the Dunn's post hoc test to examine whether differences occurred among the three time periods.

Multiple regression analyses were conducted to determine which watershed and climatic variables had the greatest effect on atrazine reservoir concentrations. Eight atrazine response variables, along with seven watershed and climatic variables, were identified for inclusion in the analyses. The eight atrazine response variables included the mean, median, maximum, minimum, 95 percentile, postapplication (June to October) mean, standard deviation, and number of months within a year that atrazine concentration exceeded the drinking water standard $(3 \mu \mathrm{g}$
$\left.\mathrm{L}^{-1}\right)$. These eight atrazine response variables were calculated on an annual basis and were used as the dependent variables in the multiple regression analyses. Watershed variables were obtained from EQIP enrollment records while cropland records were obtained from the National Agricultural Statistics Service. Watershed characteristics used as independent variables included total EQIP hectares adopting the NRCS 595 practice, total EQIP hectares adopting other conservation practices (i.e., NRCS 328, conservation crop rotation; NRCS 329, no-till tillage; NRCS 344, residue management; and NRCS 590, nutrient management), total corn hectares, total soybean hectares, and total wheat hectares. Climatic variables included total annual precipitation and total precipitation during May and June. Precipitation data were determined from averaging National Oceanic and Atmospheric Association (NOAA) data recorded within and near the watershed at the Westerville and Centerburg, Ohio, gauges.

Prior to conducting the multiple regression analyses, all pairwise correlations between independent variables were examined to ensure that the analyses were not influenced by multicollinearity $(r>0.8)$. The initial correlation analyses found that the amount of area adopting EQIP NRCS 595 and amount of area adopting other EQIP conservation practices were highly correlated $(r=0.85, p<0.001)$. In order to address the multicollinearity, the amount of area adopting other EQIP practices was transformed. Transformation of an independent variable is a common practice that enables the degree of multicollinearity to be reduced within multiple regression analyses. After transformation, 
pairwise correlations among all independent variables were less than 0.68 .

Hydrology variables were not included as independent variables because initial analyses indicated that many of these variables (annual mean discharge, mean spring discharge, mean growing season discharge) were highly correlated $(r>0.8)$ with total annual precipitation or May through June precipitation. Precipitation variables were included rather than hydrology variables because previous research (Stone and Gilliam 2009) have documented that precipitation, particularly total precipitation in May and June, is a highly influential variable on atrazine concentrations in streams and reservoirs in the United States. Eight multiple regression tests were conducted to obtain the standardized coefficients and determine which watershed and climatic variable had the greatest influence on atrazine response variables. All statistical analyses were conducted with SigmaStat 3.5 statistical software (Systat Software 2006) with a significance level of $p<0.05$.

\section{Results and Discussion}

The frequency of monthly concentrations exceeding the $3 \mu \mathrm{g} \mathrm{L}^{-1}$ drinking water standard decreased following the label restrictions and again following implementation of EQIP (figure 2). Mean monthly atrazine concentration in Hoover Reservoir was significantly $(p<0.05)$ different among the three time periods (figure 3). Additionally, the mean reservoir atrazine concentrations decreased in each subsequent time period. This suggests that the first restrictions on atrazine application (1993 to 1998) helped to reduce concentrations in the reservoir and is consistent with findings on atrazine concentrations in Midwestern streams reported by Scribner et al. (2000). This also implies that the EQIP program, through the promotion of NRCS 595 , may have led to further reductions in reservoir atrazine concentrations. Significant $(p<0.05)$ differences in mean reservoir atrazine concentration by month were also measured (figure 4). As expected, atrazine concentrations were least during the normal planting season (April and May), peaked in July and August following the period with larger runoff events, and then declined (figure 4). However, no interaction effects between time period and months were detected. These EQIP-related reductions in reservoir atrazine concentrations are consistent with previous assessments (Ohio EPA 2009).

\section{Figure 2}

Exceedence probability of monthly atrazine concentrations in Hoover Reservoir for periods 1985 to 1992 (no atrazine restrictions), 1993 to 1998 (atrazine label change), and 1999 to 2005 (atrazine label change plus special Environmental Quality Incentives Program). Solid line represents $3 \mu \mathrm{g} \mathrm{L^{-1 }}$ drinking water standard.

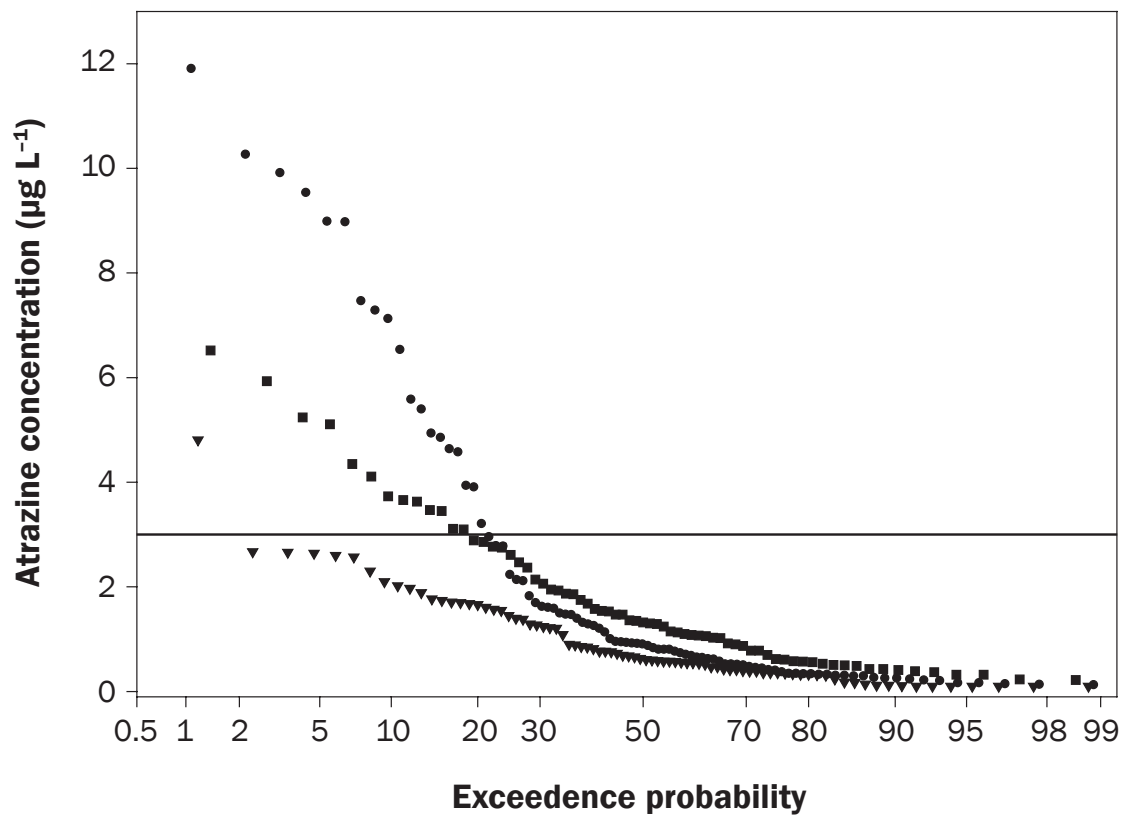

Legend

- 1985 to $1992 \quad$ V 1999 to 2005

- 1993 to 1998 Drinking water standard

Potential EQIP-related reductions were also documented in June 2002 as atrazine concentrations within an adjacent central Ohio watershed that did not receive special EQIP funds (i.e., Upper Scioto River) were greater than atrazine concentrations within the UBWC (Ohio EPA 2009). Additionally, the atrazine levels during June 2002 required the water treatment plant in the Upper Scioto River to implement PAC treatment, but PAC treatment was not required within the UBWC (Ohio EPA 2009).

Previous studies have documented that atrazine loss is positively correlated with atrazine usage, precipitation, and the amount of watershed area planted to corn (Struger and Fletcher 2007; Stone and Gilliam 2009). Information on atrazine usage within the UBWC was not available due to federal privacy regulations, thus the amount of corn planted was used as a surrogate for atrazine usage. In this study, no significant differences in annual or April through June precipitation amounts occurred among the three time periods (figures 5 and 6). The general trend in annual corn hectares within the UBWC showed a decline while the hectares of soy- beans increased and wheat area was constant (figure 7). However, no significant difference $(p=0.155)$ in median corn hectares planted occurred across the three time periods.

The multiple regression results (table 2) indicated that total precipitation in May and June had the greatest influence on five of the eight atrazine response variables (maximum, minimum, 95th percentile, postapplication mean, and standard deviation). The hectares enrolled in NRCS 595 had the greatest influence on the other three atrazine response variables (mean, median, and number of months greater than the drinking water standard) (table 2). The multiple regression analyses also indicated that the amount of hectares enrolled in other EQIP conservation practices and the amount of hectares in corn, soybeans, and wheat had a minimal influence on reservoir atrazine concentrations (table 2). The multiple regression results suggest that total precipitation in May and June and the total hectares enrolled in NRCS 595 are the primary watershed and climatic variables influencing reservoir atrazine concentrations within the Hoover Reservoir. The multiple regression results with respect 


\section{Figure 3}

Mean monthly atrazine concentrations (whiskers represent standard error) in Hoover Reservoir when no label restrictions were present (1985 to 1992; Period 1), after label restrictions were applied (1993 to 1998; Period 2), and following implementation of EQIP targeting atrazine reduction (1999 to 2005; Period 3). Different letters indicate that mean concentrations are significantly $(p<0.05)$ different: Period 1 vs. Period $2(p=0.048)$, Period 1 vs. Period $3(p<0.01)$, and Period 2 vs. Period $3(p=0.012)$.

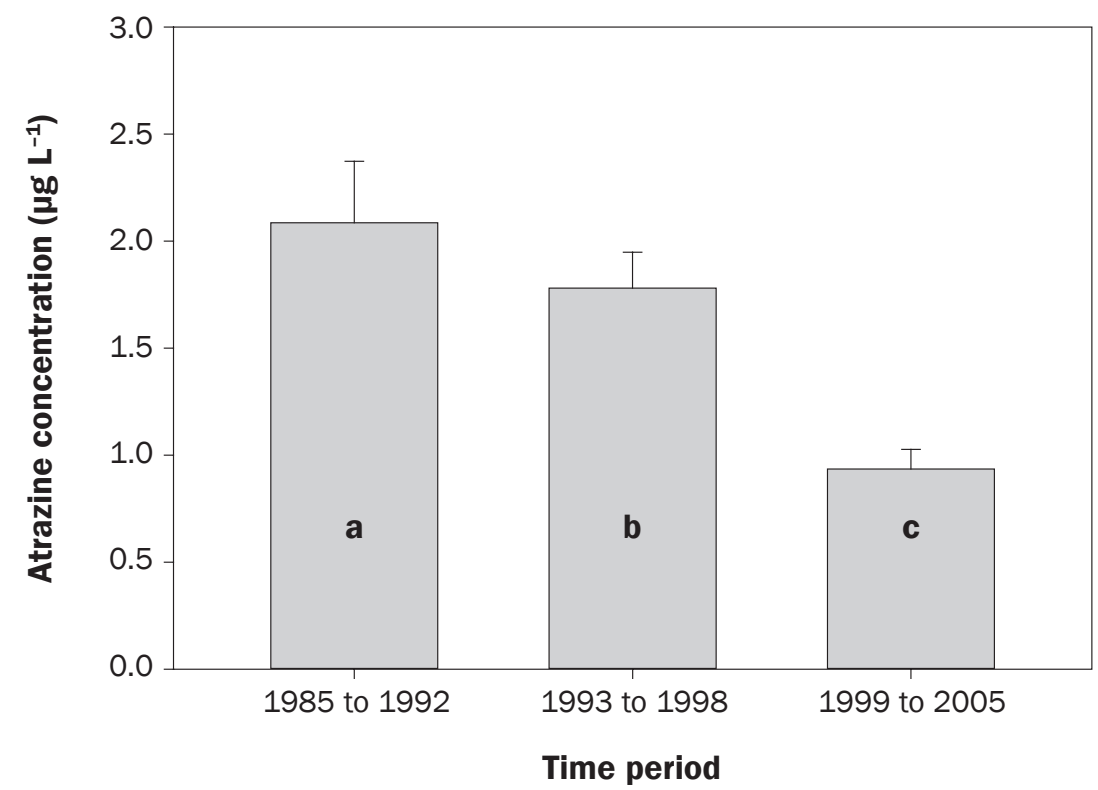

\section{Figure 4}

Mean monthly atrazine concentrations measured near Hoover Reservoir Dam for the three atrazine management periods. Error bars represent standard error.

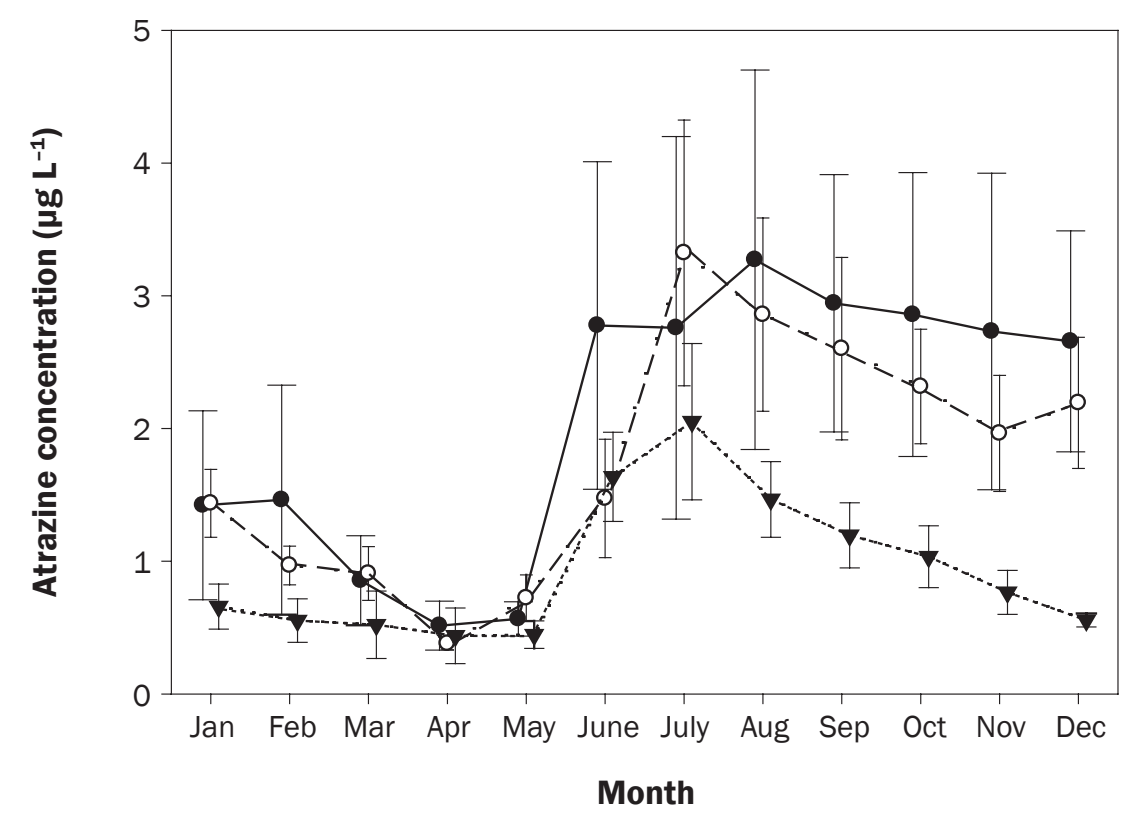

Legend to the importance of total precipitation in May and June are consistent with those of Stone and Gilliam (2009) who also observed that precipitation in May and June was one of six influential variables influencing atrazine concentrations in streams and reservoirs in the United States. Additionally, the sign associated with the standardized coefficients (table 2) consistently indicated that reservoir atrazine concentrations were positively correlated with May through June precipitation (positive sign) and reservoir atrazine concentrations were negatively correlated with hectares enrolled in NRCS 595 (negative sign). This finding also suggests that the use of EQIP and NRCS 595 helped reduce the atrazine concentrations in the reservoir.

In 2003, approximately two-thirds of the UBWC area planted in corn received EQIP payments for atrazine management. However, this area represented only $16 \%$ of the total agricultural cropland. These results suggest that eliminating atrazine usage on two-thirds of the planted corn area on an annual basis may have contributed to decreases in reservoir concentrations below the drinking water standard.

These study results, in conjunction with related water treatment and local community economic information, provide some insight to the benefits of agricultural conservation programs. A case study using City of Columbus information follows. In 1997, the City of Columbus brought a new powdered activated carbon (PAC) feeder system on line and documented the amount of PAC used. PAC is often used by drinking water purveyors for odor control and also for scrubbing pesticides, such as atrazine, from raw waters. In 1998, no PAC was used because of a dry spring period. So, 1997 is the only time period prior to EQIP with available data on PAC usage. Using the average of 1997 and 1998 amounts as a baseline, the amount and cost of PAC that the City of Columbus saved in subsequent years were estimated. The City of Columbus Division of Water saved an estimated US $\$ 1.6$ million by not having to purchase and feed PAC for atrazine from 1999 through 2005 (table 3). The carbon cost savings during the 1999 to 2005 EQIP time period would have been much higher, but the price of activated carbon fell from near US $\$ 1,240 \mathrm{t}^{-1}$ (US\$1,125 $\mathrm{tn}^{-1}$ ) in 1999 and before to near US $\$ 562 \mathrm{t}^{-1}$ (US $\$ 510 \mathrm{tn}^{-1}$ ) since the beginning of 2005. Considering the amount of monies spent on EQIP con- 


\section{Figure 5}

Total April to June precipitation during three atrazine management periods. Like letters within each box indicate no significant difference between periods $(p=0.213)$. Whiskers represent standard error.

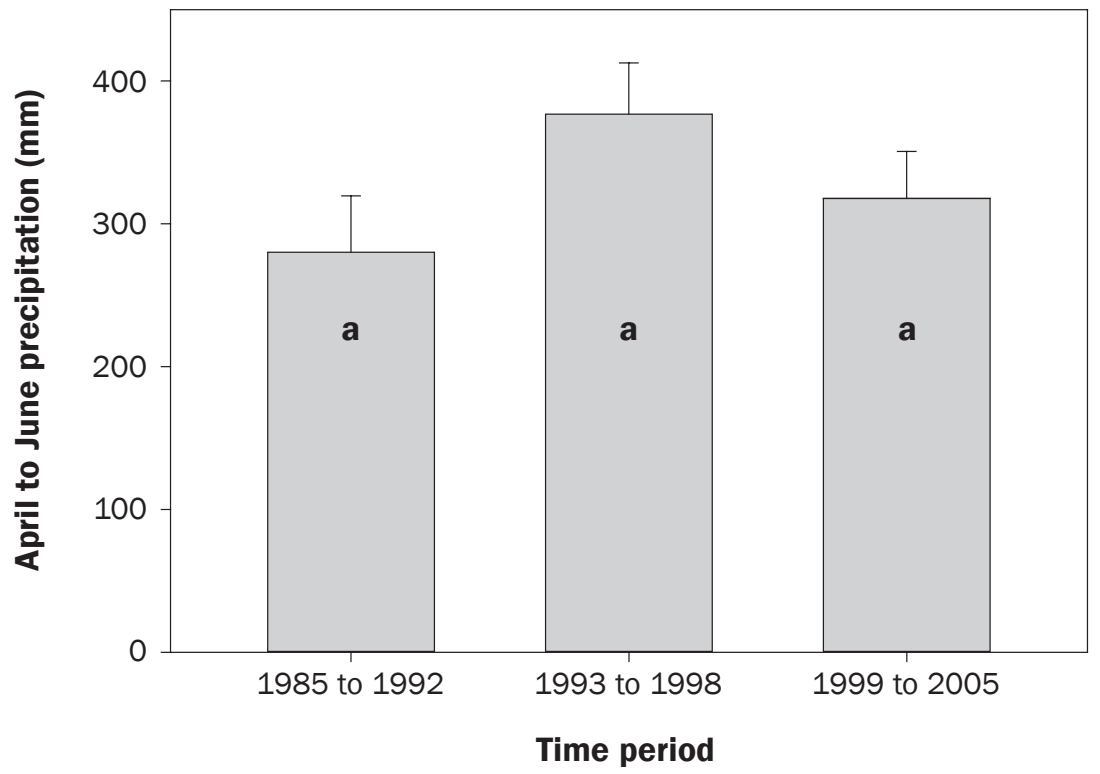

\section{Figure 6}

Annual precipitation during the three atrazine management periods. Like letters within each box indicate no significant difference between periods $(p=0.912)$. Whiskers represent standard error.

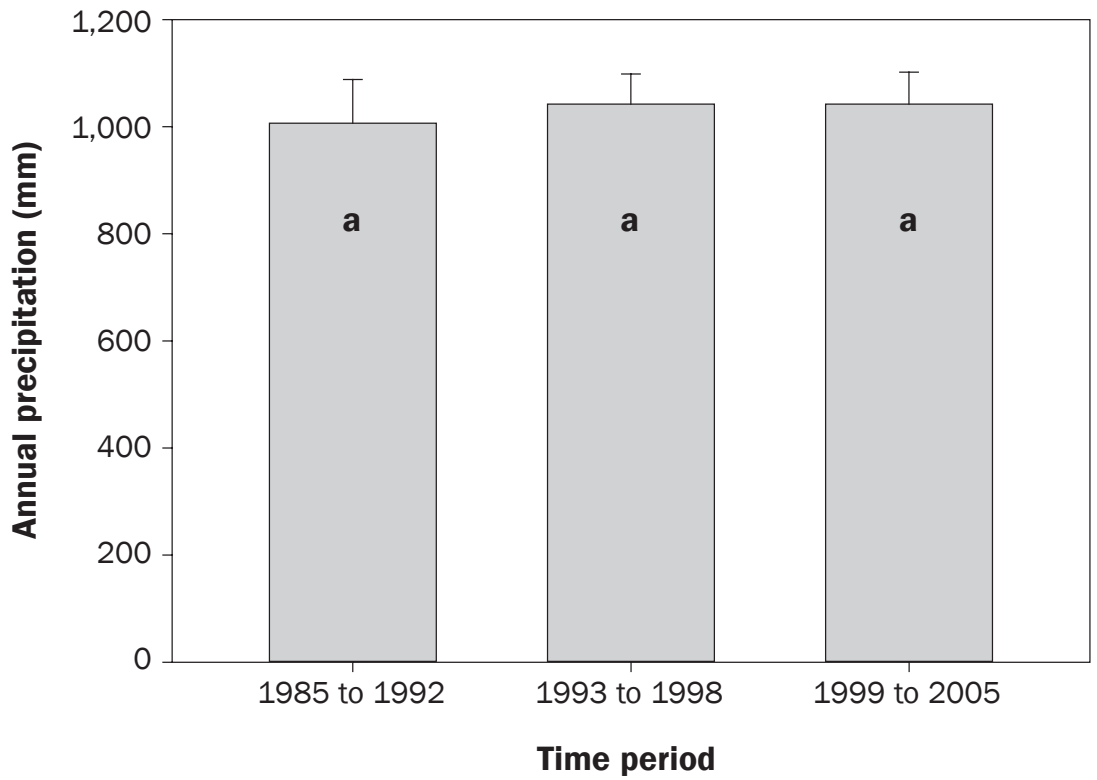

servation practices within the watershed, a US $\$ 2.04$ drinking water treatment cost savings was realized for every dollar spent on EQIP cost share from 1999 through 2005. If only the pest management or atrazine reduction practice (i.e., NRCS 595) allocations were used in the calculation, the return was US\$2.73 for every dollar spent.

Residents in the five central Ohio counties within and adjacent to the UBWC and Hoover reservoir were surveyed via mail to determine their willingness to pay into a local conservation fund for certain environmental improvements through BMPs (Tennity 2005). Although this survey did not directly calculate the value of reducing atrazine in this watershed, it did examine how local citizens would value improvements in drinking water. Specifically, the survey found that local residents would be willing to pay US $\$ 1.7$ million per year to reduce the number of drinks of Columbus water with poor taste or bad odor by $5 \%$. The special EQIP program aimed at reducing atrazine applied in the watershed appears to have contributed to the reduction in the number of atrazine exceedences greater than the drinking water standard by greater than $90 \%$ (figure 3). It is not possible to correlate atrazine concentration exceedences with drinking water taste and odor as examined in this survey, but these results are instructive nonetheless. If citizens value atrazine reduction as much as improved drinking water taste and odor, then they could be willing to pay up to US $\$ 1.7$ million per year for the atrazine management program to continue. Over a seven year period, the EQIP program actually spent only US\$814,000, and the benefits likely greatly outweigh the costs.

\section{Summary and Conclusions}

Conservation practice dollars paid to farmers in the UBWC appear to have contributed to reductions in atrazine concentrations in Hoover Reservoir, a major drinking water source for Columbus, Ohio. Since the late 1980 s, atrazine concentrations in this reservoir periodically exceeded the health advisory limit of $3 \mu \mathrm{g} \mathrm{L} \mathrm{L}^{-1}$. To reduce these elevated concentrations of atrazine, the City of Columbus used PAC to filter all the drinking water, incurring high water treatment costs. Starting in 1999, farmers were paid through EQIP for adopting one of four management options to reduce atrazine application on the fields they enrolled in this program. During 


\section{Figure 7}

Trend in corn, soybeans, and wheat hectares within the watershed for the period of 1985 to 2005.

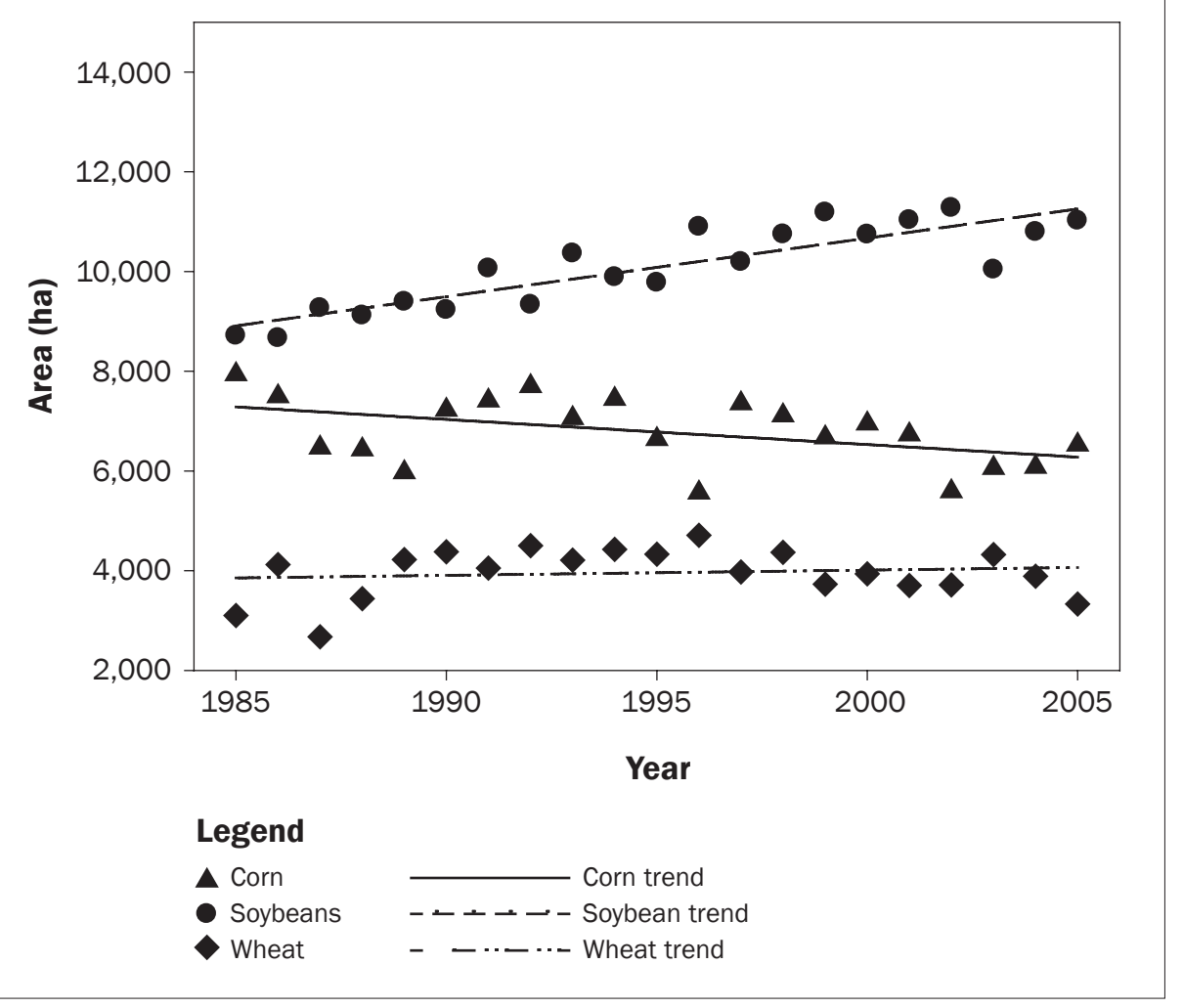

the assessment period following EQIP implementation, only one monthly concentration exceeded the maximum contaminant level. From a financial standpoint, for every dollar spent to implement the conservation program, a US $\$ 2.04$ savings was realized by the City of Columbus in reduced purchases of PAC to remove atrazine from the source water of the drinking water supply.
Additionally, residents in this watershed indicated a willingness to pay into a water quality improvement fund annually in the amount of US\$1.7 million for improved drinking water quality (taste and odor removal). This suggests residents are willing to pay twice as much annually for drinking water quality improvement as NRCS provided for EQIP throughout the entire seven year EQIP period within this watershed. These findings highlight the potential water quality and economic benefits of voluntary watershed-scale reductions in atrazine application within agricultural watersheds for the protection of surface drinking water sources that are threatened by excess atrazine concentrations.

\section{Acknowledgements}

The authors acknowledge and thank the following individuals for their contributions to the manuscript: Denise Shafer (district conservationist, Delaware County, Ohio,) for providing input to the acreage and dollars spent on EQIP; Larry Ufferman, Ed Miller, and Bret Bacon (Delaware County Soil and Water Conservation District) for database management; and the entire staff of the Delaware, Morrow, Knox, and Licking County Soil and Water Conservation Districts for providing education about the program and locating farmers to participate in the EQIP.

America's Clean Water Foundation initiated a Source Water Protection Initiative at the Federal level to support research within the UBWC to develop innovative agricultural management practices for reducing atrazine concentrations in drinking water supply reservoirs and streams. The US Congress supported this initiative with funding for research to the USDA Agricultural Research Service beginning in FY 2001 with increases in FY 2002 and FY 2003.

\section{References}

Brian, R. 1995. Weed killers by the glass. Washington, DC: Environmental Working Group.

Bryant, R.B., T.L. Veith, P.J.A. Kleinman, and W.J. Gburek 2008. Cannonsville Reservoir and Town Brook watersheds: Documenting conservation efforts to protect New York City's drinking water. Journal of Soil and Water Conservation 63(6):339-344, doi:10.2489/ jswc.63.6.339.

Conover, W.J. 1999. Practical Nonparametric Statistics. New York: Wiley.

\section{Table 2}

Standardized coefficient values from multiple regression of mean, median, maximum, minimum, 95 percentile, postapplication (June to October) mean, standard deviation, and number of months above the drinking water standard $\left(3 \mu \mathrm{gL}^{-1}\right)$ reservoir atrazine concentrations with total hectares adopting Natural Resources Conservation Service 595, percentage of hectares adopting other Environmental Quality Incentives Program conservation practices (Other EQIP), corn hectares, soybean hectares, wheat hectares, total annual precipitation, and total May to June precipitation within Upper Big Walnut Creek watershed, 1985 to 2005. Bolded standardized coefficients are those with the greatest value within a row.

\begin{tabular}{|c|c|c|c|c|c|c|c|}
\hline Response variable & 595 & $\begin{array}{l}\text { Other } \\
\text { EQIP }\end{array}$ & Corn & Soybean & Wheat & $\begin{array}{l}\text { Annual } \\
\text { precipitation }\end{array}$ & $\begin{array}{l}\text { May to June } \\
\text { precipitation }\end{array}$ \\
\hline Mean & -0.52 & 0.13 & -0.18 & -0.11 & -0.01 & 0.30 & 0.49 \\
\hline Maximum & -0.47 & 0.26 & -0.10 & -0.16 & -0.02 & 0.37 & 0.54 \\
\hline Minimum & -0.04 & -0.23 & 0.30 & 0.24 & 0.37 & -0.28 & 0.42 \\
\hline 95 percentile & -0.46 & 0.20 & -0.14 & -0.15 & -0.04 & 0.32 & 0.55 \\
\hline Number of months $>3 \mu g \mathrm{~L}^{-1}$ & -0.62 & 0.09 & -0.33 & -0.12 & -0.05 & 0.31 & 0.48 \\
\hline
\end{tabular}


Table 3

Cost and estimated savings for powdered activated carbon (PAC) for atrazine treatment by City of Columbus.

\begin{tabular}{lcccl}
\hline Year & $\begin{array}{l}\text { PAC } \\
\text { used } \mathbf{( t )}\end{array}$ & $\begin{array}{l}\text { Cost } \\
\left(\mathbf{U S} \mathbf{\$} \mathbf{t}^{\mathbf{1}} \text { ) }\right.\end{array}$ & $\begin{array}{l}\text { PAC } \\
\text { amount } \\
\text { spent (US\$) }\end{array}$ & $\begin{array}{l}\text { Amount saved compared } \\
\text { to average of 1997 and } \\
\mathbf{1 9 9 8} \text { PAC expenses (US\$) }\end{array}$ \\
\hline 1997 & 900 & 1,102 & 992,416 & NA \\
1998 & 0 & 1,240 & 0 & NA \\
\hline Average & 450 & - & - & NA \\
\hline 1999 & 0 & 1,240 & 0 & 558,000 \\
2000 & 478 & 961 & 459,786 & 0 \\
2001 & 234 & 1,008 & 235,853 & 217,728 \\
2002 & 0 & 523 & 0 & 235,350 \\
2003 & 162 & 534 & 86,517 & 153,792 \\
2004 & 0 & 545 & 0 & 245,250 \\
2005 & 0 & 562 & 0 & 252,900 \\
\hline Total & - & - & - & $1,663,020$ \\
\hline Note: & PAC amount used in 2000 was greater than the average of 1997 and 1998.
\end{tabular}

Coupe, R.H., and J.D. Blomquist. 2004. Water-soluble pesticides in finished water of community water supplies. Journal of the American Water Works Association 96:56-68.

Davies, J.M., and A. Mazumber. 2003. Health and environmental policy issues in Canada: The role of watershed management in sustaining clean drinking water quality at surface sources. Journal of Environmental Management 68:273-286.

Devlin, D.L., D.L. Regehr, and P.L. Barnes. 2000. Managing to minimize atrazine runoff. Kansas State University Agricultural Experiment Station and Cooperative Extension Service MF2208, February 2000. Manhattan, KS: Kansas State University.

Gorneau, W.S., T.G. Franti, B.L. Benham, and S.D. Comfort. 2001. Reducing long-term atrazine runoff from south central Nebraska. Transactions American Society of Agricultural and Biological Engineers 44:45-52.

Hargrove, W.L., and D. Devlin. 2010.The road to clean water: Building collaboration and stakeholder relationships. Journal of Soil and Water Conservation 65:104A-110A, doi:10.2489/jswc.65.5.104A.

Kenny,J.F, N.L. Barber, S.S. Hutson, K.S. Linsey,J.K. Lovelace, and M.A. Maupin. 2009. Estimated use of water in the United States in 2005. US Geological Survey Circular 1344. Reston,VA: US Geological Survey.

King, K.W., P.C. Smiley, Jr., B.J. Baker, and N.R. Fausey. 2008. Validation of paired watersheds for assessing conservation practices in the Upper Big Walnut Creek watershed, Ohio. Journal Soil and Water Conservation 63(6):380-395, doi:10.2489/jswc.63.6.380.

Malcom Pirnie Inc. 1999. Upper BigWalnut Creek Watershed Water Quality Management Plan. Columbus, Ohio.

Mausbach, M.J., and A.R. Dedrick. 2004. The length we go: Measuring environmental benefits of conservation practices. Journal of Soil and Water Conservation 59:96A-103A.

Meals, D.W., S.A. Dressing, and T.E. Davenport. 2010. Lag time in water quality response to best management practices: A review. Journal of Environmental Quality 39:85-96

Mickelson, S.K., J.L. Baker, and S.I. Ahmed. 2003.Vegetative filter strips for reducing atrazine and sediment runoff transport. Journal Soil and Water Conservation 58:359-367.
Moore, M.T., J.H. Rodgers, Jr., C.M. Cooper, and S. Smith, Jr. 2000. Constructed wetlands for mitigation of atrazineassociated agricultural runoff. Environmental Pollution 110:393-399.

Ohio EPA (Environmental Protection Agency). 2005. Total Maximum Daily Loads for the Big Walnut Creek Watershed. Final Report. Columbus, OH: State of Ohio Environmental Protection Agency, Division of Surface Water.

Ohio EPA. 2008. Ohio 2008 integrated water quality monitoring and assessment report. Columbus, $\mathrm{OH}$ : State of Ohio Environmental Protection Agency, Division of Surface Water.

Ohio EPA. 2009. Developing source water protection plans for public drinking water systems using inland surface waters. Columbus, $\mathrm{OH}$ : State of Ohio Environmental Protection Agency, Division of Surface Water and Division of Drinking and Ground Waters.

Ohio EPA. 2010. Ohio 2010 integrated water quality monitoring and assessment report. Columbus, $\mathrm{OH}$ : State of Ohio Environmental Protection Agency, Division of Surface Water.

Postel, S.L., and B.H. Thompson, Jr. 2005. Watershed protection: Capturing the benefits of nature's water supply services. Natural Resources Forum 29:98-108.

Rector, R.J., D.L. Regehr, P.L. Barnes, T.M. Loughin, and M.A. Hoobler. 2003. Application timing impact on runoff losses of atrazine. Weed Science 51:817-825.

Reichenberger, S., M. Bach, a. Skitschak, and H.G. Frede. 2007. Mitigation strategies to reduce pesticide inputs into ground- and surface water and their effectiveness: A review. Science of the Total Environment 384:1-35.

Ribaudo, M.O., and A. Bouzaher. 1994. Atrazine: Environmental Characteristics and Economics of Management Economic Research Service, US Department of Agriculture. Agricultural Economic Report No. 699. Washington, DC: USDA.

Ritter, L., K. Solomon, P. Sibley, K. Hall, P. Keen, G. Mattu, and B. Linton. 2002. Sources, pathways, and relative risks of contaminants in surface water and groundwater: A perspective prepared for the Walkerton Inquiry. Journal of Toxicology and Environmental Health, Part A $65: 1-142$.

Rohr, J.R., and K.A. McCoy. 2010. A qualitative metaanalysis reveals consistent effects of atrazine on freshwater fish and amphibians. Environmental Health Perspectives 118:20-32

Scribner, E.A., W.A. Battaglin, D.A. Goolsby, and E.M. Thurman. 2000. Changes in herbicide concentrations in Midwestern streams in relation to changes in use, 19891998. Science of the Total Environment 248:255-263.

Smiley, P.C., Jr., K.W. King, and N.R. Fausey. 2010. Public health perspectives of channelized and unchannelized headwater streams in central Ohio: A case study. Journal of Water and Health Journal of Water and Health 8:577-592.

Smithers, J., and M. Furman. 2003. Environmental farm planning in Ontario: Exploring participation and the endurance of change. Land Use Policy 20:343-356.

Stackelberg, P.E., E.T. Furlong, M.T. Meyer, S.D. Zaugg, A.K. Henderson, and D.B. Reissman. 2004. Persistence of pharmaceutical compounds and other organic wastewater contaminants in a conventional drinkingwater-treatment plant. Science of the Total Environment 329:99-113

Stone, W.W., and R.J. Gilliom. 2009. Update of watershed regressions for pesticides (WARP) for predicting atrazine concentration in streams: USGS Open-File Report 2009-1122. Reston,VA: US Geological Survey.

Struger, J., and T. Fletcher. 2007. Occurrence of lawn care and agricultural pesticides in the Don River and Humber River watersheds (1998-2002). Journal of Great Lakes Research 33:887-905.

Systat Software. 2006. SigmaStat 3.5 for Windows. Point Richmond, CA: Systat Software.

Tennity, C. 2005. A conjoint analysis study of perceived demand in Central Ohio for specific agricultural natural resource conservation practices. Master's thesis. The Ohio State University.

USEPA (US Environmental Protection Agency). 2006 Decision documents for atrazine. Washington, DC: USEPA.

USEPA. 1995. Method 507: Determination of nitrogen and phosphorus containing pesticides in water by gas chromatography with a nitrogen-phosphorus detector, revision 2.1.J.W.Munch, ed. National Exposure Research Laboratory Office of Research and Development. Cincinnati, OH: USEPA.

Valentin, L., D.J. Bernardo, and T.L. Kastens. 2004. Testing the empirical relationship between best management practice adoption and farm profitability. Review of Agricultural Economics 26:489-504.

Vecchia, A.V., R.J. Gilliom, D.J. Sullivan, D.L. Lorenz, and J.D. Martin. 2009. Trends in concentrations and use of agricultural herbicides for corn belt rivers, 1996-2006. Environmental Science and Technology 43:9096-9102.

Westerhoff, P., Y. Yoon, S. Snyder, and E. Wert. 2005. Fate of endocrine-disruptor, pharmaceutical, and personal care product chemicals during simulated drinking water treatment processes. Environmental Science and Technology 39:6649-6663. 